there was a lower index of suspicion for women. In a study of the alcohol consumption patterns of 371 patients admitted to the Maudsley and Bethlem hospitals there was a large measure of agreement between the researchers' diagnosis and the hospital diagnosis. ${ }^{5}$ It is unlikely that a primary diagnosis of alcoholism is being missed, but the registrars' failure to attend to other than overt alcohol problems related to alcohol when there is time to investigate such problems represents a valuable opportunity lost to influence a captive audience.

This is a small study of a teaching hospital population, and our data would benefit from comparison with those from a non-teaching hospital. Our findings suggest that the psychiatric registrars who take a quantitative alcohol history perform consistently better than their colleagues who record subjective qualitative comments. Doctors should always quantify the alcohol intake of their patients whatever the dignosis or sex. When this appears excessive then a lifetime drinking history and a daily drinking pattern should be fully documented.

We thank Professor Griffith Edwards for his help and advice in the preparation of this paper.

1 Barrison IG, Viola L, Murray-Lyon IM. Do housemen take an adequate drinking history? BrMed $\mathcal{f}$ 1980;281:1040.

2 Rowland N, Maynard A, Beveridge A, et al. Doctors have no time for alcohol screening. Br Med $\mathfrak{J}$ 1987;295:95-6.

3 Lockhart SP, Carter YH, Straffen AM, et al. Detecting alcohol consumption as a cause of emergency general medical admissions. f $R$ Soc Med 1986;79:132-6.

4 Chick J, Lloyd G, Crombie E. Counselling problem drinkers in medical wards. Br Med 1985;290:965-7.

5 Bernadt MW, Murray RM. Psychiatric disorder, drinking and alcoholism: What are the links? $B r f$ Psych 1986;148:393-400.

(Accepted 14 October 1987)

The Royal Bethlem and Maudsley Hospital, London SE5 8AZ

M P FARRELL, MRCP, MRCPSYCH, registrar in psychiatry

A S DAVID, MRCP, MRCPSYCH, registrar in psychiatry

Correspondence to: Dr Farrell.

\section{Severe orthostatic hypotension during treatment of falciparum malaria}

Chloroquine is the drug of choice for chloroquine sensitive falciparum malaria and infections caused by Plasmodium malariae, $P$ ovale, and $P$ vivax. A fixed dose combination of sulfadoxine $500 \mathrm{mg}$ and pyrimethamine $25 \mathrm{mg}$ (Fansidar) is the most commonly used treatment for chloroquine resistant malaria. Recently a fixed dose triple combination of mefloquine $250 \mathrm{mg}$, sulfadoxine $500 \mathrm{mg}$, and pyrimethamine $25 \mathrm{mg}$ (Fansimef) has also been found to be effective against chloroquine resistant malaria. ${ }^{12}$ Serious side effects from these drugs are uncommon; severe orthostatic hypotension has not been reported.

\section{Patients, methods, and results}

In combined studies 189 male patients aged 12-50 were admitted to hospital with symptomatic falciparum malaria. None was seriously ill or hypotensive (supine blood pressure measured after 10 minutes' rest, erect blood pressure measured after three minutes' standing). Patients received either a single dose of sulfadoxine $1500 \mathrm{mg}$ and pyrimethamine $75 \mathrm{mg}$ (99 patients); a single dose of mefloquine $500 \mathrm{mg}$, sulfadoxine $1000 \mathrm{mg}$, and pyrimethamine $50 \mathrm{mg}$ (50 patients); or chloroquine $1500 \mathrm{mg}$ over three days ( 40 patients). Erect and supine blood pressures were measured regularly after treatment, though at different frequencies in each study (table). In most patients there was complete clearance of asexual parasitaemia and return to normal body temperature within three days of starting treatment.
At some time during their hospital stay, however, 26 patients were found to have unrecordable blood pressures on standing (table). Some patients fainted on standing; others could stand for three minutes before fainting or feeling faint. In every case blood pressure was normal immediately before standing and had returned to normal within five minutes after resuming the supine position. One patient had a sinus bradycardia (ventricular rate $44 / \mathrm{min}$ ) immediately after an episode of postural hypotension; no other arrhythmias were recorded. Only three of the 26 patients had normal body temperature at the time of their hypotensive episodes.

Orthostatic hypotension was not associated with age, weight, severity of parasitaemia, or pretreatment blood pressure. Two of the patients in whom postural hypotension occurred had further attacks of falciparum malaria about 10 weeks later; both were treated with a further single dose of sulfadoxine $1500 \mathrm{mg}$ and pyrimethamine $75 \mathrm{mg}$. Only one had a recurrence of his postural hypotension.

\section{Comment}

Treating American servicemen, Butler and Weber found that orthostatic hypotension was a common and prominent clinical feature of malaria caused by $P$ falciparum and $P$ vivax. They attributed it to the relative bradycardia and peripheral dilatation that occurs in malaria. Attempts to improve the orthostatic hypotension by rehydrating the patients before giving them antimalarial drugs were unsuccessful. ${ }^{3}$

The patients in our series who experienced severe orthostatic hypotension did so only after antimalarial treatment had begun. An explanation may be that concentrations of blood histamine increase during attacks of falciparum malaria ${ }^{4}$ and pyrimethamine and chloroquine inhibit histamine $N$-methyltransferase, ${ }^{5}$ an enzyme responsible for histamine metabolism in the mammalian central nervous system. Together these may produce increased central effects of histamine and hypotension. That only one of 50 patients given the lower doses of sulfadoxine and pyrimethamine developed postural hypotension is consistent with this hypothesis.

Patients prescribed antimalarials for falciparum malaria and people responsible for their care should be aware of the possibility of postural hypotension.

We thank Nursing Sister $R$ A Kishombe and the nurses and technicians of the TDRC for their help. This study received financial support from the UNDP/World Bank/WHO special programme for research and training in tropical diseases. Fansimef and some of the Fansidar tablets were supplied by Hoffmann-La Roche and Co, Basle, Switzerland.

1 Kofi Ekue JM, Ulrich A-M, Rwabwogo-Atenyi J, Sheth UK. A double-blind comparative clinical trial of mefloquine and chloroquine in symptomatic falciparum malaria. Bull WHO 1983;61: trial of

2 Kofi Ekue JM, Simooya OO, Sheth UK, Wernsdorfer WH, Njelesani EK. A double-blind clinical trial with three dosage schedules of a combination of mefloquine, sulfadoxine and pyrimethamine trial with three dosage schedules of a combination of mefloquine, sulfadoxine
(Fansimef) in symptomatic falciparum malaria. Bull WHO 1985;63:339-43.

3 Butler T, Weber DM. On the nature of orthostatic hypotension in acute malaria. Am $\mathcal{F}$ Trop Med Hyg 1973;22:439-42.

4 Srichaikul T, Archararit N, Siriasawakul T. Histamine changes in Plasmodium falciparum malaria. Trans R Soc Trop Med Hyg 1976;70:36-8.

5 Duch DS, Dowers S, Edelstein $M$, Nicholl CA. Histamine: elevation of brain levels by inhibition of $\mathrm{N}$-methyltransferase. In: Usdin E, Burchardt RT, Creveling CR, eds. Transmethylation. New York: Elsevier North Holland, 1979:287-95.

(Accepted 19 October 1987)

Tropical Diseases Research Centre (TDRC), PO Box 71769, Ndola, Zambia

J M KOFI EKUE, MD, MRCP, WHO clinical pharmacologist

D E D PHIRI, MB, CHB, staff development fellow in clinical pharmacology

M MUKUNYANDELA, MB, MRCP, director

World Health Organisation, Geneva

U K SHETH, MD, clinical trials monitor, Scientific Working Group on the Chemotherapy of Malaria

W H WERNSDORFER, MD, chief, research and technical intelligence, malaria action programme

Correspondence to: Dr Kofi Ekue.

\begin{tabular}{|c|c|c|c|c|c|}
\hline Treatment & $\begin{array}{c}\text { No } \\
\text { of } \\
\text { patients }\end{array}$ & $\begin{array}{c}\text { Frequency of } \\
\text { blood pressure } \\
\text { measurement }\end{array}$ & $\begin{array}{l}\text { No with unrecordable } \\
\text { blood pressure } \\
\text { on standing }\end{array}$ & $\begin{array}{l}\text { Interval between treatment } \\
\text { and onset of hypotension } \\
\text { (h) }\end{array}$ & $\begin{array}{l}\text { Duration of } \\
\text { hypotension } \\
\text { (h) }\end{array}$ \\
\hline \multirow{3}{*}{ Sulfadoxine $1500 \mathrm{mg}$, pyrimethamine $75 \mathrm{mg}$} & 150 & Daily & 10 & $14-48$ & $24-72$ \\
\hline & $\{39$ & 8 Hourly & 10 & $9-44$ & $6-40$ \\
\hline & 10 & Hourly for $24 \mathrm{~h}$, then 8 hourly & 2 & 14,16 & $5-24$ \\
\hline Mefloquine $500 \mathrm{mg}$, sulfadoxine $1000 \mathrm{mg}$, pyrimethamine $50 \mathrm{mg}$ & 50 & Daily & 1 & 15 & 24 \\
\hline Chloroquine $1500 \mathrm{mg}$ & 40 & Hourly for $24 \mathrm{~h}$, then 8 hourly & 3 & $2-4$ & $3-12$ \\
\hline
\end{tabular}

